\title{
MAB
}

\section{Binnengekomen boeken}

Onroerend-goed belasting: hoe en wat

Kluwer belastingwijzers 18

A. Bangma/J. P. Kruimel

Prijs: $f 26,50$

Van de BV en de NV

Achtste druk

Mr. P. van Schilfgaarde

Uitgever: Gouda Quint B.V.

Issues in management accounting D. Ashton, T. Hopper, R. W. Scapens

Uitgever: Prentice Hall, Hemel

Hempstead

Prijs: $£ 30,95$

Trends in Transport 90/91

Uitgever: Delwel Uitgeverij B.V.,

Den Haag

Prijs: $f$ 85,-

Accounting for management decisions

Tweede druk

J. Arnold/T. Hope

Uitgever: Prentice Hall, Hemel

Hempstead

Prijs: ₹ 32,95
FMA-Kroniek 1990

C. D. Knoops, J. Dijksma, W. M. du Pon

Uitgever: Wolters-Noordhoff,

Groningen

Prijs: $f$ 96,-

\section{Bouw}

Financieel-economisch brancheboek bouwnijverheid

1990-1991

Uitgever: Delwel Uitgeverij B.V.,

Den Haag

Prijs: $f 49,90$

Het Europees Economisch

Samenwerkingsverband

Mr. M. van Olffen/Mr. P. A. J. Beks

Uitgever: Tjeenk Willink, Zwolle

Prijs: $f$ 44,-

Fiscale aspecten van NV's en BV's Vijfde druk

Prof. Dr. J. C. K. W. Bartel

Prof. Dr. J. H. Christiaanse

Uitgever: Kluwer, Deventer

Prijs: $f$ 49,50

\section{Belastingcontrole}

Derde druk

R. Kamerling, P. Dekker

Kluwer belastingwijzers 17

Prijs: $f 29,50$
Verliescompensatie

Tweede herziene druk

Serie Fiscale Monografieën

Prof. Dr. J. W. Zwemmer

Uitgever: Kluwer, Deventer

Prijs: $f$ 47,50

Strategische Samenwerking

Cooper \& Lybrand Dijker Van Dien

Uitgever: Samsom Bedrijfsinformatie,

Alphen a/d Rijn

Een eigenzinnige koers

40 jaar Faculteit Econ.

Wetenschappen Groningen

T. Kastelein, K. Bijsterveld, $H$. van

der Meulen

Uitgever: Rijksuniversiteit Groningen

Prijs: $f$ 45,- 